\title{
Pengaruh Mckenzie Cervical Exercise terhadap Nyeri Leher Pekerja Home Industry Tahu
}

\author{
Octavia Nurhidayanti ${ }^{1}$, Elis Hartati ${ }^{2}$, Prita Adisty Handayani ${ }^{1 *}$ \\ ${ }^{1}$ STIKES Telogorejo, Semarang, Indonesia \\ ${ }^{2}$ Universitas Diponegoro, Semarang, Indonesia \\ pritaadisty@stikestelogorejo.ac.id
}

\begin{abstract}
Introduction: Occupational health problems in the home industry are found in many work-related diseases and unsafe workplace conditions, one of the diseases arising from work is musculoskeletal complaints. Mckenzie cervical exercise can reduce neck pain however it has not been proven for home industry workers. This study aims to determine the effect of Mckenzie cervical exercise on the scale of neck pain on workers in tofu home industry.

Methods: This research design used pre-experimental design with one-group pre-posttest design. The number of samples were 30 respondents with a total sampling technique. The instrument was the Numeric Rating Scale and data were collected using interview techniques.

Results: Workers with neck pain in the "tahu" home industry were provided Mckenzie cervical exercise. The statistical test used was the dependent t-test. The results showed that Mckenzie cervical exercise is effective in reducing the scale of neck pain with a p-value of 0.000 .

Conclusion: The recommendations of this study are for routine workers to perform Mckenzie cervical exercise therapy in each implementation in order to help reduce the scale of neck pain in tofu home industry workers.
\end{abstract}

Keywords: Home Industry, Mckenzie Exercise, Neck Pain, Worker

\section{ABSTRAK}

Pendahuluan: Masalah kesehatan kerja pada home industry banyak ditemukan penyakit yang berkaitan dengan pekerjaan dan kondisi tempat kerja yang tidak aman, salah satu penyakit yang timbul akibat kerja adalah keluhan muskuloskeletal. Mckenzie cervical exercise merupakan latihan untuk mengurangi rasa nyeri leher namun latihan ini belum dibuktikan pada nyeri leher pekerja home industry. Penelitian ini bertujuan untuk mengetahui pengaruh Mckenzie cervical exercise terhadap nyeri leher pada pekerja home industry tahu.

Metode: Penelitian ini menggunakan pre-experimental design dengan one-group pre-posttest design. Jumlah sampel pada penelitian ini sebanyak 30 responden dengan total sampling. Instrumen yang digunakan berupa Numeric Rating Scale dan pengambilan data dilakukan dengan teknik wawancara.

Hasil: Pekerja home industry tahu yang mengalami nyeri leher diberikan Mckenzie cervical exercise. Uji statistik yang digunakan adalah dependent t-test. Hasil penelitian menunjukkan bahwa mckenzie cervical exercise efektif untuk menurunkan skala nyeri leher dengan p-value 0,000 .

Kesimpulan: Rekomendasi penelitian ini agar pekerja rutin melakukan terapi Mckenzie cervical exercise ditiap pelaksanaan agar dapat membantu menurunkan skala nyeri leher pada pekerja home industry tahu.

Kata Kunci: Industri Rumahan, Mckenzie Exercise, Nyeri Leher, Pekerja 


\section{PENDAHULUAN}

Dampak pekerjaan dalam waktu yang lama dengan posisi yang tetap atau sama baik berdiri, duduk maupun menunduk akan menyebabkan ketidaknyamanan. Posisi kerja berdiri yang terlalu lama akan membuat pekerja selalu berusaha menyeimbangkan posisi tubuhnya sehingga menyebabkan terjadinya beban kerja statis pada otot-otot punggung dan kaki, kondisi tersebut juga menyebabkan mengumpulnya darah pada anggota tubuh bagian bawah, sedangkan posisi duduk yang terlalu lama tanpa adanya penyesuaian dapat mengakibatkan melengkungnya tulang belakang dan low back pain, menunduk atau mendongak terlalu lama juga akan mengakibatkan berubahnya posisi alamiah di bagian tulang cervical sehingga dapat mengakibatkan nyeri leher (Fauziah, Karim \& Utami, 2018).

Nyeri leher merupakan masalah yang umum ditemukan dua dari tiga orang akan mengalaminya selama hidup. Leher manusia merupakan struktur yang kompleks dan sangat rentan terhadap iritasi, bahkan $10 \%$ dari semua orang akan mengalami nyeri leher dalam satu bulan. Potensi pembangkit nyeri termasuk tulang, otot, ligamen, sendi dan diskus intervertebralis. Hampir setiap cedera atau proses penyakit pada struktur leher atau yang berdekatan akan menghasilkan spasme otot dan hilangnya fungsi gerak (Permana, 2017).

Berdasarkan data dari WHO Global Plan of Action on Workers' Health 20082017 tercatat bahwa keluhan muskuloskeletal berada diurutan kedua terbanyak penyakit akibat kerja setelah penyakit saluran pernapasan (Tubagus, Doda, \& Wungouw, 2018). Data statistik
Labour Forse Survey (LFS) menunjukkan keluhan muskuloskeletal pada pekerja sangat tinggi yaitu sejumlah 1.144.000 kasus dengan distribusi kasus yang menyerang punggung sebesar 493.000 kasus, anggota tubuh bagian atas atau leher 426.000 kasus dan anggota tubuh bagian bawah 224.000 kasus. Gangguan musuloskeletal pada 12.213 kasus di Jawa Tengah menunjukkan angka tertinggi diraih oleh anggota gerak bawah $(68,3 \%)$, anggota gerak atas $(30,7 \%)$, leher $(10,6 \%)$, punggung $(6,4 \%)$, dan dada $(1,9 \%)$ (Kementerian Kesehatan Republik Indonesia, 2018).

Penanganan masalah nyeri leher dapat dilakukan dengan pemberian terapi latihan. Terapi latihan adalah gerak tubuh, postur atau aktivitas fisik yang dilakukan secara sistematis dan terencana guna memberikan manfaat untuk memperbaiki, mengembalikan dan menambah fungsi fisik. Terapi latihan juga dapat untuk mencegah atau mengurangi faktor risiko terkait kesehatan (Kisner \& Colby, 2016). Mckenzie cervical exercise merupakan bentuk latihan untuk mengurangi rasa nyeri leher serta dapat meningkatkan fleksibilitas otot leher, membantu mengurangi spasme pada otot, meningkatkan lingkup gerak sendi yang terbatas, serta mengembalikan postur leher pada posisi anatomisnya. Tujuannya adalah mengatasi masalah nyeri leher atau punggung dengan berlatih secara mandiri sehingga pasien dapat beraktivitas, dan mengembalikan fungsional tubuh. Latihan ini mempunyai manfaat yang cukup besar terhadap perubahan nilai keterbatasan gerak sendi, serta terbukti dapat mengurangi rasa nyeri (Winaya et al., 2019). Prosedur terapi latihan Mckenzie cervical exercise meliputi head retraction 
in sitting, neck extension in sitting, side bending of the neck, neck rotation, dan neck flection in sitting (McKenzie, 2014). Mckenzie cervical exercise sangat efektif dalam meningkatkan lingkup gerak sendi yang terbatas selain itu juga dapat mengurangi rasa nyeri, namun latihan ini belum dibuktikan pada nyeri leher pekerja home industry tahu. Penelitian ini bertujuan untuk mengetahui pengaruh Mckenzie cervical exercise terhadap nyeri leher pekerja home industry tahu.

\section{METODE}

Penelitian ini menggunakan desain penelitian pre-experimental design dengan one-group pre-posttest. Responden dilakukan pengukuran (observasi) sebelum dan sesudah perlakuan yaitu terapi Mckenzie cervical exercise. Terapi diberikan pada pekerja yang mengalami nyeri leher. Prosedur terapi latihan Mckenzie cervical exercise meliputi head retraction in sitting, neck extension in sitting, side bending of the neck, neck rotation, dan neck flection in sitting. Terapi Mckenzie cervical exercise di lakukan pada 16 April - 06 Mei 2020, terapi ini diberikan selama 3 minggu sebanyak 9 kali dan saat pemberian terapi dilakukan di rumah responden. Penelitian ini menggunakan teknik total sampling dengan populasi pekerja home industry tahu. Terdapat 30 responden yang memenuhi kriteria inklusi yaitu pekerja home industry tahu dengan keluhan nyeri leher, belum pernah terpapar Mckenzie cervical exercise, dan

usia 30 - 60 tahun. Instrumen yang digunakan berupa Numeric Rating Scale yaitu skala nyeri (0-10) dan pengambilan data dilakukan dengan teknik wawancara. Uji statistik yang digunakan pada penelitian ini adalah dependent t-test.

Octavia Nurhidayanti, dkk., Pengaruh Mckenzie Cervical Exercise...

\section{HASIL PENELITIAN}

Tabel 1. Jenis Kelamin Pekerja Home Industri Tahu $(\mathrm{n}=30)$

\begin{tabular}{ccc}
\hline Variabel & F & \% \\
\hline Jenis kelamin & & \\
Laki-Laki & 27 & $90 \%$ \\
Perempuan & 3 & $10 \%$ \\
Jumlah & 30 & $100 \%$ \\
\hline
\end{tabular}

Berdasarkan data pada tabel 1 . Dapat dijelaskan bahwa jenis kelamin lakilaki sebanyak 27 responden (90\%) mengalami keluhan nyeri leher. Keluhan nyeri leher ini mayoritas sering terjadi pada laki-laki dari pada perempuan.

Tabel 2. Gambaran karakteristik responden

\begin{tabular}{lcc}
\hline \multicolumn{1}{c}{ Variabel } & Median & Min-Max \\
\hline Usia & 45 & $30-55$ \\
\hline Lama kerja & 8 & $8-9$ \\
\hline Masa kerja & 6,50 & $2-10$ \\
\hline
\end{tabular}

Berdasarkan data pada Tabel 1 diperoleh data bahwa nilai tengah lama kerja adalah 8 jam, lama kerja minimum 8 jam dan maksimum 9 jam. Saat bekerja postur tubuh yang dilakukan pekerja home industry tahu kurang baik atau tidak ergonomis, karena pekerja home industry tahu bekerja dengan posisi berdiri dan sering menunduk, posisi ini di lakukan setiap hari kurang lebih 8-9 jam. Pada karakteristik masa kerja nilai tengah atau median yaitu 6,50 tahun, masa kerja minimum 2 tahun dan masa kerja maksimum 10 tahun. Keluhan nyeri leher ini dirasakan pada pekerja home industry tahu yang sudah bekerja selama 2 tahun ke atas. 
Tabel 3. Pengaruh Mckenzie Cerviacal

Exercise terhadap Skala Nyeri Leher pada Pekerja Home Industry Tahu

\begin{tabular}{|c|c|c|c|c|c|}
\hline \multirow{2}{*}{$\begin{array}{c}\text { Variab } \\
\text { el }\end{array}$} & \multicolumn{2}{|c|}{ Pre Test } & \multicolumn{2}{|c|}{ Post Ttest } & \multirow{2}{*}{$\begin{array}{c}p- \\
\text { valu } \\
e\end{array}$} \\
\hline & $x \pm \mathrm{SD}$ & $\begin{array}{l}\mathbf{M i} \\
\mathbf{n}- \\
\mathbf{M a} \\
\mathbf{x}\end{array}$ & $x \pm S D$ & $\begin{array}{l}\text { Mi } \\
\text { n - } \\
\text { Ma }\end{array}$ & \\
\hline $\begin{array}{l}\text { Skala } \\
\text { nyeri } \\
\text { leher }\end{array}$ & $\begin{array}{c}4,27 \pm \\
1,285\end{array}$ & $\begin{array}{l}2- \\
7\end{array}$ & $\begin{array}{l}3,03 \pm \\
1,245\end{array}$ & $\begin{array}{l}1- \\
6\end{array}$ & $\begin{array}{l}0,00 \\
0\end{array}$ \\
\hline
\end{tabular}

\section{Keterangan:}

$x$ : mean atau rata-rata

SD : standar deviation

Tabel 3 menunjukkan hasil analisis bahwa skala nyeri leher sebelum dan sesudah dilakukan terapi mckenzie cervical exercise menunjukkan perbedaan yang signifikan dengan $p$-value $=0,000(<0,05)$. Hal ini berarti bahwa Mckenzie cervical exercise dapat menurunkan nyeri leher pada pekerja home industry tahu.

\section{PEMBAHASAN}

\section{Jenis Kelamin}

Jenis kelamin berkaitan erat dengan keluhan musculoskeletal disorders hal ini dikarenakan secara fisiologis laki-laki lebih kuat di bandingkan perempuan. Jenis kelamin menunjukkan pengaruh yang signifikan terhadap keluhan otot. Kekuatan otot yang dimiliki perempuan lebih kecil jika dibandingkan dengan laki-laki. Lakilaki juga memiliki risiko mengalami gangguan muskuloskeletal karena beban kerja yang lebih besar dibanding perempuan. Hal ini dapat menyebabkan kelelahan pada otot yang dapat menimbulkan keluhan nyeri (Habibie, Diani \& Hafifah, 2019).

Penelitian ini menunjukkan bahwa 90\% responden berjenis kelamin laki-laki.
Keluhan nyeri leher ini mayoritas sering terjadi pada laki-laki dari pada perempuan. Keluhan yang sering terjadi pada pekerja laki-laki yaitu nyeri leher, punggung dan bahu. Keluhan yang sering dirasakan pekerja perempuan yaitu nyeri leher dan punggung.

Wanita memiliki hormon esterogen dan progresteron yang berfungsi menjaga kekenyalan otot dan ligamen. Wanita yang sudah menopouse mengalami ketidakseimbangan hormon esterogen dan progesteron sehingga menyebabkan pengeroposan tulang dan ligamen. Kondisi ini membuat wanita dapat mengalami keluhan musculoskeletal disorders (Ardyatma, 2015). Jenis kelamin laki-laki maupun perempuan memiliki risiko yang sama terhadap keluhan muskuloskeletal disorders. Prevalensi cedera tulang belakang lebih tinggi terjadi pada laki-laki daripada perempuan, hal tersebut juga tergantung jenis pekerjaan yang dijalaninya. Berat ringannya beban kerja seorang tenaga kerja menentukan berapa lama seseorang tenaga kerja melakukan aktivitas pekerjaannya sesuai dengan kemampuan atau kapasitas kerja yang bersangkutan. Kondisi beban kerja, cara mengangkat barang dan lain-lain mempengaruhi kelelahan seseorang, akumulasi beban kerja fisik ini bisa mengakibatkan otot semakin berkontraksi dan mengakibatkan adanya keluhan muskuloskeletal (Saleh, 2018).

\section{Usia}

Usia merupakan faktor yang banyak berperan untuk terjadinya nyeri leher yang terlokalisir. Usia berpengaruh terhadap keluhan nyeri leher berkaitan dengan proses penuaan seiring bertambahnya usia, termasuk degenerasi tulang yang Octavia Nurhidayanti, dkk., Pengaruh Mckenzie Cervical Exercise... 
berdampak pada peningkatan risiko nyeri leher. Usia menengah yaitu 40 tahun merupakan usia yang berpeluang besar mendapatkan risiko nyeri (Karaeng, Djajakusli \& Naiem, 2013). Semakin tua usia seseorang maka semakin tinggi terjadinya keluhan otot, dan seseorang yang bekerja dengan waktu yang lama dan diiringi dengan meningkatnya umur maka akan terjadi proses degenerasi yang berakibat kepada berkurangnya stabilitas pada tulang dan otot (Habibie, Diani \& Hafifah, 2019).

Hasil penelitian menunjukkan bahwa nilai tengah usia adalah 45 tahun, usia termuda 30 tahun dan tertua 55 tahun. Penelitian Priyanka (2019) pada pembatik Giriloyo terdapat usia 25-31 tahun (5\%), $32-38$ tahun (13\%), 39-45 tahun (25\%), 4652 tahun (20\%), 53-59 tahun (20\%) dan 6066 tahun (6\%). Frekuensi usia pada pembatik Giriloyo tertinggi terdapat pada kelompok usia 39-45 tahun yaitu 25 orang mengalami nyeri leher.

Keluhan sistem muskuloskeletal mulai dirasakan pada pekerja biasanya keluhan pertama dirasakan pada usia 35 tahun dan keluhan tersebut terus meningkat dengan bertambahnya usia. Kekuatan otot maksimal terjadi pada usia 20-29 tahun dan penurunan sejalan dengan bertambah usia. Pada usia 60 tahun kekuatan otot menurun sampai $20 \%$ yang mempunyai faktor risiko terjadinya keluhan otot akan meningkat. Insiden keluhan nyeri leher sering terjadi pada usia antara 31 sampai 50 tahun, usia menengah yaitu 40 tahun merupakan usia yang berpeluang besar untuk terjadinya keluhan nyeri leher (Permana, 2017). Usia sebagai salah satu indentitas individu dikaitkan dengan kejadian kecelakaan akibat kerja. Kelompok usia tua memiliki kecenderungan yang lebih tinggi mengalami kecelakaan kerja dibandingkan dengan usia muda yang memiliki kegesitan yang tinggi. Seiring bertambahnya usia maka individu tersebut akan menjadi lebih rentan terhadap penyakit, kecacatan, dan organ tubuh akan mengalami penurunan fungsi. Semakin bertambahnya usia seseorang akan dapat memicu timbulnya gangguan kesehatan kususnya pada tulang belakang. Gangguan muskuloskeletal akan terus meningkat selama 25 tahun kedepan (Saleh, 2018). Seseorang mengalami kemunduran seperti regenerasi jaringan ke jaringan parut, penurunan cairan dan kerusakan jaringan pada usia 30 tahun. Hal ini dapat mengakibatkan stabilitas di otot dan tulang menurun. Semakin bertambahnya usia individu, maka semakin tinggi risiko individu mengalami kemerosotan elastisitas di tulang (Habibie, Diani \& Hafifah, 2019).

\section{Lama Kerja}

Penelitian menunjukkan bahwa pekerja home industry tahu bekerja selama 8 jam per hari. Lama kerja minimum 8 jam dan lama kerja maximum 9 jam. Pekerja home industry tahu dengan lama kerja 8 jam ataupun $>8$ jam memiliki risiko untuk mengalami nyeri leher dibandingkan dengan pekerja yang memiliki lama kerja $<8$ jam.

Lama kerja adalah waktu bekerja termasuk juga waktu istirahat, waktu kerja dari seseorang menentukan efisiensi dan produktifitasnya. Seseorang dapat bekerja dengan baik dengan durasi 8 jam perhari, durasi lama kerja berkaitan dengan keadaan fisik tubuh pekerja, pekerjaan fisik yang berat akan mempengaruhi kerja otot, kardiovaskuler, sistem pernapasan dan lainya. Jika pekerjaan berlangsung dalam Cervical Exercise... 
waktu yang lama tanpa istirahat, kemampuan tubuh akan menurun dan dapat menyebabkan kesakitan pada anggota tubuh (Icsal, Sabilu \& Pratiwi, 2016).

Lama kerja dengan keluhan nyeri leher, pada pembatik dengan lama kerja 4-7 jam (17\%), 8 jam (65\%), dan lebih dari 8 jam (18\%) mengeluh merasakan nyeri leher. Semakin tinggi lama kerja pembatik semakin tinggi risiko pembatik mengalami nyeri leher (Priyanka, 2019).

Lama kerja mempengaruhi nyeri leher karena lama kerja yang tinggi ditambah dengan karakteristik pekerja yang harus menunduk secara terus menerus akan menyebabkan otot-otot pada daerah leher berkontraksi terus menerus yang dapat mengakibatkan kelelahan pada otot leher. Apabila kondisi ini berulang maka dapat mengakibatkan spasme otot dan dapat mengakibatkan nyeri leher. Sikap kerja tidak alamiah terjadi karena karakteristik tuntutan tugas, alat kerja, area kerja tidak sesuai dengan kemampuan dan keterbatasan kerja. Beban statis ditimbulkan akibat otot dalam keadaan tegang tanpa menghasilkan gerakan dan postur tubuh dalam kondisi tidak alamiah, dalam hal ini akan mengakibatkan nyeri leher. Pekerja yang bekerja 41-48 jam/ minggu atau rata-rata 7-8 jam perhari menyebabkan waktu istirahat yang berkurang dan kerja otot lebih berat sehingga risiko nyeri leher akan meningkat (Utami, Karimuna \& Jufri, 2017). Lama kerja dapat mempengaruhi kejadian keluhan nyeri leher, 67 dari 100 responden mengeluhkan nyeri leher. Semakin lama kerja seseorang dapat menurunkan produktivitas kerja, timbulnya kelelahan serta dapat mengakibatkan penyakit dan kecelakaan akibat kerja (Lestari, 2015).
Keluhan otot skeletal pada umumnya terjadi karena kontraksi otot yang berlebihan akibat pemberian kerja yang terlalu berat atau gerakan statis dengan durasi pembebanan yang panjang. Wijayati (2020) menyatakan bahwa postur tubuh yang tidak alamiah terjadi saat bagian tubuh bergerak menjauhi posisi alamiah yaitu seperti posisi kepala terangkat dan leher terlalu menunduk yang terlalu lama. Postur statis merupakan postur saat kerja fisik dalam posisi yang sama dimana pergerakan yang terjadi sangat minim atau gerakan yang dipertahankan lebih 10 detik. Lama mempertahankan postur kerja dapat juga diartikan sebagai lamanya waktu atau durasi paparan terhadap faktor risiko cidera yang akan terjadi, jika pekerjaan berlangsung dalam waktu yang lama, maka kemampuan tubuh akan menurun dan menyebabkan keluhan pada tubuh.

\section{Masa Kerja}

Hasil penelitian menunjukkan bahwa masa kerja pekerja home industry tahu dengan nilai tengah atau median yaitu 6,50 tahun. Masa Kerja minimum 2 tahun dan masa kerja maximum 10 tahun. Pekerja home industry tahu sudah mulai berkerja pada saat usia dewasa awal, semakin lama masa kerja pekerja maka akumulasi pembebanan otot leher akibat aktivitas statis leher sehari-hari pada pekerja akan semakin meningkat. Pembebanan otot akan terakumulasi setiap harinya sehingga dapat meningkatkan risiko gangguan pada leher.

Masa kerja membuktikan lamanya individu terkena paparan di tempat kerja, semakin lama individu bekerja maka semakin lama terkena paparan di tempat kerja yang dapat mengakibatkan terjadinya gangguan muskuloskeletal (Habibie, Diani \& Hafifah, 2019). Masa kerja merupakan 
faktor risiko yang sangat mempengaruhi seorang pekerja untuk meningkatkan risiko gangguan muskuloskeletal, terutama untuk jenis pekerjaan yang menggunakan kekuatan kerja yang tinggi. Masa kerja yang lama dapat berpengaruh terhadap nyeri leher karena merupakan akumulasi pembebanan pada otot leher. Leher yang bergerak kedepan sebesar 1 inchi akan meningkatkan berat kepala pada leher sebesar 10 pound. Jika leher bergerak 3 inchi ke depan maka akan meningkatkan berat kepala pada leher sebesar 30 pound dan tekanan pada otot-otot leher meningkat 6 kali. Postur tidak baik ini dalam jangka panjang akan menimbulkan nyeri leher (Karaeng, Djajakusli \& Naiem, 2013).

$$
\text { Penelitian Priyanka }
$$

menunjukkan bahwa pembatik dengan masa kerja 6-10 tahun (5\%) dan masa kerja $>10$ tahun (95\%) mengeluhkan nyeri leher. Hasil penelitian menyimpulkan semakin tinggi masa kerja pembatik semakin tinggi risiko pembatik mengalami nyeri leher. Cindyastira, Russeng \& Wahyuni (2014) menjelaskan semakin lama masa kerja seseorang maka semakin lama keterpaparan terhadap waktu dan jenis pekerjaan yang dilakukan oleh pekerja, sehingga akan menimbulkan berbagai keluhan-keluhan fisik akibat pekerjaannya. Masa kerja $>5$ tahun memiliki risiko mengalami nyeri leher lebih tinggi 4,444 kali lebih tinggi dibandingkan masa kerja $<5$ tahun.

\section{Pengaruh McKenzie Cervical Exercise}

Hasil penelitian menunjukkan bahwa terdapat perbedaan skala nyeri leher sebelum dan sesudah dilakukan terapi mckenzie cervical exercise. Hasil ini sesuai dengan penelitian Dwianto (2016) yang menyimpulkan bahwa latihan Mckenzie efektif dalam mengurangi nyeri punggung bawah.

Trisnowiyanto (2017) menjelaskan bahwa penguluran otot dapat menurunkan nyeri dan meningkatkan kemampuan fungsional leher pada penderita nyeri leher. Prinsip penguluran otot atau peregangan maupun exercise dapat memperpanjang jaringan lunak dan mengalami pemendekan dengan demikian dapat meningkatkan fleksibilitas gerak.

Pertiwi et al. (2017) menjelaskan bahwa Mckenzie exercise yaitu self-healing dan self-treatment yang merupakan hal terpenting untuk rehabilitasi dan meredakan rasa nyeri. Manfaat yang didapat dari pemberian latihan ini yang lebih kepada adanya indikasi nyeri pada jaringan otot, kapsul sendi dan gangguan saraf melalui penguluran tulang belakang dan otot yang dilakukan pada sepanjang gerakan latihan dengan repetisi yang telah ditentukan sebelumnya dapat memperbaiki atau mengoreksi postur yang salah saat beraktivitas baik statis maupun dinamis. Latihan ini dapat mengembalikan alignment leher secara normal, membebaskan kekakuan pada intervetebral joints yang diakibatkan oleh spasme otot yang dibiarkan berkelanjutan akibat postur tubuh yang salah saat beraktivitas, dan yang terakhir memberikan efek muscle elongation. Latihan Mckenzie merupakan salah satu jenis latihan punggung yang berfungsi untuk memperbaiki posture dan meningkatkan mobilitas tulang belakang. Pemberian latihan Mckenzie dapat memberikan efek rileksasi pada otot setelah kontraksi maksimal sehingga menimbulkan efek inhibisi pada otot yang spasme (Nahdliyyah \& Prastiwi, 2014). 
Prosedur latihan mckenzie yang pertama yaitu gerakan head retraction in sitting merupakan gerakan yang sangat penting karena latihan ini digunakan terutama dalam pengobatan nyeri leher. Gerakan kedua yaitu neck extension in sitting merupakan gerakan yang digunakan untuk pengobatan dan pencegahan nyeri leher. Gerakan ketiga yaitu side bending of the neck merupakan latihan yang digunakan khusus untuk pengobatan rasa sakit yang dirasakan hanya di satu sisi atau rasa sakit lebih terasa disatu sisi dari pada yang lain. Gerakan kempat yaitu neck rotation merupakan latihan yang baik untuk perawatan nyeri seperti kekakuan leher. Gerakan kelima yaitu neckflection in sitting merupakan latihan yang berguna untuk pengobatan sakit kepala, tetapi juga bisa diterapkan untuk mengatasi sisa nyeri leher atau kekakuan (McKenzie, 2014).

Penelitian ini menunjukkan bahwa delapan responden yang tidak mengalami penurunan skala nyeri diakibatkan karena pada saat melakukan terapi Mckenzie cervical exercise responden kurang mengulur dan menekan bagian leher. Hal ini dikarenakan responden merasa cemas apabila nyeri yang dirasakan semakin meningkat. Timbulnya rasa nyeri yang menyerang secara tiba-tiba pada penderita nyeri ini sangat mengganggu, dimana akan timbul rasa cemas dan was-was apabila sewaktu-waktu penyakit ini menyerang dengan rasa nyeri yang sangat sakit. Adanya keluhan tersebut dapat membuat penderita merasa cemas jika keluhan kambuh kembali, kecemasan merupakan rasa tidak nyaman sebagai suatu bentuk manifestasi rasa ketakutan akan kehilangan sesuatu yang penting atau terjadi peristiwa buruk dalam kondisi yang ada. Faktor pencetus terjadinya kecemasan tersebut bersifat lebih umum, penyebab kecemasan dapat berasal dari berbagai kejadian di dalam kehidupan atau terletak di dalam diri seseorang, misalnya seseorang yang memiliki pengalaman dalam menjalani suatu tindakan maka dalam dirinya akan lebih mampu beradaptasi atau kecemasan yang timbul tidak terlalu besar (Adawiyah, Astuti, \& Rosmiati, 2019).

\section{KESIMPULAN DAN SARAN}

Berdasarkan hasil penelitian di kelurahan Gedang Anak maka dapat disimpulkan sebagai berikut: pengaruh mckenzie cervical exercise terhadap skala nyeri leher pada pekerja home industry tahu di Kelurahan Gedang Anak Ungaran Timur, diketahui nilai $p$-value $0,000(<0,05)$. Maka mckenzie cervical exercise mampu menurunkan skala nyeri leher pada pekerja home industry tahu.

Peneliti menyarankan kepada beberapa pihak meliputi pekerja, petugas kesehatan, institusi pendidikan keperawatan, dan penelit selanjutnya. Pekerja diharapkan dapat melakukan terapi Mckenzie cervical exercise di sela-sela pekerjaan, saat istirahat dan setelah bekerja dengan tujuan untuk menjaga sirkulasi darah tetap lancar agar otot tidak mengalami spasme dan tidak terjadi keluhan nyeri leher. Petugas kesehatan disarankan untuk lebih mengaplikasikan Mckenzie cervical exercise untuk mengurangi skala nyeri leher. Institusi pendidikan diharapkan memasukan materi Mckenzie cervical exercise pada topik yang berkaitan dengan pengurangan nyeri leher pada pekerja seperti Occupational Health Nursing. Penelitian selanjutnya dapat membandingkan Mckenzie cervical exercise dengan intervensi pengurang nyeri 
leher lain atau melakukan penelitian serupa dengan menambahkan kelompok kontrol.

\section{DAFTAR PUSTAKA}

Adawiyah, R., Astuti, Astuti, F., \& Rosmiati, Y. (2019). Hubungan nyeri dengan kecemasan pada Lansia di Balai Sosial Lanjut Usia Mandalika Mataram Provinsi NTB. Prima, 5(1), $40-45$.

Ardyatma, C. (2015). Perbedaan angka kejadian nyeri muskuloskeletal antara pria dan wanita pada kelompok tani nira di Dusun Ngudi Mulyo Pajangan Bantul. Universitas Muhammadiyah Surakarta.

Cindyastira, D., Russeng, S. S. \& Wahyuni, A. (2014). Hubungan intensitas getaran dengan keluhan Musculoskeletal Disorders (MSDs). Jurnal MKMI, 10(4), 234-240.

Dwianto, I. H. (2016). Efektivitas latihan Mc. Kenzie dalam pengurangan nyeri punggung bawah muskuloskeletal. Jurnal Penelitian Kesehatan, 6(1), 2631

Fauziah, N., Karim, D., \& Utami, S. (2018). Hubungan Antara Posisi Tubuh dengan Keluhan Muskuloskeletal pada Petani di Desa Silongo Kecamatan Lubuk Tarok Kabupaten Sijunjung. Jurnal Online Mahasiswa, 5(2), 244250.

Habibie, H., Diani, N., \& Hafifah, I. (2019). Hubungan umur, jenis kelamin dan kebiasaan olahraga dengan Keluhan Musculoskeletal Disorders (MSDs) Pada Perawat. Caring Nursing, 3(1), 23-30.

Icsal, M., Sabilu, Y., \& Pratiwi, A.D. (2016). Faktor yang berhubungan dengan keluhan Musculoskeletal Disorders (MSDs) pada penjahit wilayah Pasar Panjang Kota Kediri.
Jurnal Ilmiah Mahasiswa Kesehatan Masyarakat, 1(2), 1-8.

Karaeng, M., Djajakusli, R., \& Naiem, M. F. (2013). Hubungan beban kerja dengan nyeri leher pada tenaga kerja bongkar muat di Koperasi Tenaga Kerja Bongkar Muat Pelabuhan Makassar. Diperoleh dari https://core.ac.uk/download/pdf/2549 0172.pdf

Kisner, C. \& Colby, L. A. (2016). Terapi latihan dasar dan teknik. (6th Ed.) Jakarta: EGC.

Lestari, B. (2015). Faktor-faktor yang mempengaruhi terjadinya nyeri leher pada pengguna laptop. Universitas Muhammadiyan Surakarta.

McKenzie, R. (2014). 7 steps to a pain-free life how to rapidly relieve back, neck, and shoulder pain. New York: Penguin Group.

Nahdliyyah, A. I., \& Prastiwi, D. (2014). Pengaruh terapi latihan Mc Kenzie mengurangi keterbatasan gerak thoracal pada pekerja batik dengan keluhan joint blockade thoracal. Pena Jurnal Ilmu Pengetahuan dan Teknologi, 28(2), 230-236.

Permana, A. I. (2017). Hubungan antara lama duduk pengemudi bis terhadap risiko terjadinya kondisi neck pain. Universitas Muhammadiyah Surakarta.

Pertiwi, J. K., Tirtayasa, K., Sugijanto, Pangkahila, J. A., Muliarta, I M. \& Lesmana, S. I. (2017). Kombinasi McKenzie exercise dan ultrasound lebih baik daripada myofascial release dan ultrasound untuk memperbaiki disabilitas pada mechanical neck pain. Jurnal Sport and Fitness, volume 5(3), 78-84. doi: 10.24843/spj.2017.v05.i03.p11 
Yani, F., Anniza, M., \& Priyanka, K. (2019). Hubungan masa kerja dan lama kerja dengan nyeri leher pada pembatik di Sentra Batik Giriloyo. Jurnal Ergonomi Indonesia, 6(1), 3136 , doi: 10.24843/JEI.2020.v06.i01.p04

Kementerian Kesehatan Republik Indonesia. (2018). Laporan Nasional_Riskesdas 2018. Diperoleh dari

http://repository.litbang.kemkes.go.id/ 3514/1/Laporan\%20Riskesdas\%2020 $18 \% 20$ Nasional.pdf

Saleh, L. M. (2018). Man behind the scene aviation safety. Yogyakarta: Deepublish.

Trisnowiyanto, B. (2017). Teknik penguluran otot-otot leher untuk meningkatkan fungsional leher pada penderita nyeri tengkuk non-spesifik. Jurnal Kesehatan Terpadu, 1(1), 6-11.

Tubagus, A. P., Doda, D. V. D., \& Wungouw, H. I. S. (2018). Hubungan tingkat risiko Musculoskeletal Disorders (MSDs) menggunakan Rapid Entire Body Assessment (REBA) dengan keluhan MSDs pada residen ilmu bedah. Jurnal Biomedik, 10(3), 168-173. Doi: 10.35790/jbm.10.3.2018.21982

Utami, U., Karimuna, S. R., \& Jufri, N. (2017). Hubungan lama kerja, sikap kerja dan beban kerja dengan Muskuloskeletal Disorders (MSDs) pada petani padi di Desa Ahuhu Kecamatan Meluhu Kabupaten Konawe Tahun 2017. Jurnal Ilmiah Mahasiswa Kesehatan Masyarakat, 2(6), 1-10. doi: 10.37887/jimkesmas.v2i6.2921

Wijayati, E. W. (2020). Risiko postur kerja terhadap keluhan subyektif nyeri Leher pada pekerja industri kerajinan kulit. Jurnal Ilmiah Penelitian Kesehatan, 5(1), 56-64.

Winaya, I. M. K., Tianing, N. W., Widnyana, M. \& Putra, I. P. Y. P. (2019). Perbedaan efektivitas intervensi microwave diathermy dan deep tissue massage lebih efektif daripada microwave diathermy dan Mckenzie neck exercise untuk koreksi postur pada penderita forward head posture. Jurnal Sport and Fitness, 7(2), 51-63. 